\title{
Abundance of the groupers fish (Teleostei: Serranidae) along Gulf of Aqaba
}

\author{
Belal M. Saleh ${ }^{2}$, Mohammed M. Abozeid ${ }^{1}$, Ashraf I. Ahmed ${ }^{2}$, Magdy A. Alwany ${ }^{2}$, M. El-Sherbiny ${ }^{2}$ \\ ${ }^{1}$ Marine biology department, Faculty of Science, Al-Azhar University \\ ${ }^{2}$ Marine Science Department Faculty of Science Suez Canal University
}

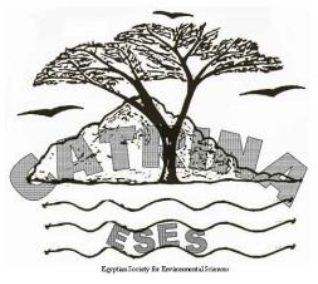

\begin{abstract}
The groupers abundance was studied in sixteen stations representing four sites along the Gulf of Aqaba. Sixteen species belonging to five genera of groupers were recorded across the four sites. The mean abundance of all groupers species in Ras Mohamed NP and Sharm El Sheikh City were found to be higher than that of Nabq and Abu Galum MRPA. The highest abundance of groupers were recorded in Ras Nasrani (76 SE \pm 2.08 ) and Ras Um Sid (71 SE \pm 2.0 ). There was no significant difference of groupers abundance between depths of $5 \mathrm{~m}$ and $15 \mathrm{~m}$ in all of the studied sites. Based on their ecological behavior, groupers were divided into separate groups, and abundance was investigated for each group. Abundance of the cryptic and roving groupers was higher than that of the large mobile groupers, in all of the studied sites. While cryptic and roving grouper included both abundance and rare species, large mobile groupers species were all rare. The pattern of occurrence for the three different groups was repeated in all sites, except for Abu Galum MRPA where no large mobile grouper was recorded, probably due to over fishing. Diversity of groupers in all of the studied sites increased with the increase of abundance.
\end{abstract}

Keywords: Coral reef, Epinephelinae, fish abundance, Groupers, Gulf of Aqaba, Res Sea, Serranidae, South Sinai protectorates.

\section{INTRODUCTION}

Studies of community structure in coral reef systems are of increasing importance at present and directly beneficial to managers of reef fisheries and reefs management for tourism and other purposes. Groupers (Family: Serranidae) are one of the largest groups of tropical fish with over 400 known species (Wolf, 1999). They are considered as one of the toplevel of predators and has a high market value, that cause this group became the most important around the world (JEFRI et $a l ., 2015)$. This property makes it an important component of reef ecosystems, helping to maintain the ecological balance of complex coral reef communities (Sluka et al., 1996). Because of their trophic position near the top of the food chain, they can act as health indicators of the reef ecosystem. Consequently, the reliable data on the abundance and distribution of Groupers is important for sound management of these fishes as well as to provide a foundation for understandding groupers distribution and reef fish life history strategies (Pogonoski et al., 2002). Little information exists on patterns of abundance for the majority epinepheline species (Pogonoski et al., 2002). The main exception is for Plectropomus leopardus on the Great Barrier Reef, as considerable information has been collected on patterns of abundance for this commercial species since 1980 (Ayling et al., 2000; Mapstone et al., 2004).

Groupers are less studied than many other fish (Parrish 1987). Furthermore, known to consume a broad range of prey including fish, crabs, shrimps and other benthic crustaceans although there is considerable variation among species. Groupers are generally associated with hard bottoms, while juveniles are found in seagrass beds, and adults of smaller number species prefer silty or sandy areas (Prokop, 2002). Some species such as Variola spp. occur in depths of 100 to $200 \mathrm{~m}$, however, the majority inhabit areas less than $100 \mathrm{~m}$ in depth (Heemstra and Randall, 1993). Although the popular of groupers are widespread, they face several threats including habitat destruction and over fishing (Sullivan and Sluka, 1996; Dalzell, 1996; Birkeland, 1997).

Habitat dependence among fish families has shown to be stronger in Groupers, which lead a relatively sedentary life (Parish, 1987; Lindberg et al., 2006). Groupers make use of shelters and even when visually exposed, often remain close to large masses of hard substrate (Ormond, 1980). Reef complexity and habitat features a strong influence on the success of predatory strategies either directly by altering the effectiveness of the ambush strategies (Samoilys, 1997; Auster, 2005). Otherwise, indirectly by changing the density of the resources of small fish, crustaceans and other types of prey (Almany, 2004). In addition, their slow growth rates, long life and relatively low fertility (Grandcourt $2005)$, that put them in danger due to both natural and human impact (Sadovy et al., 2012). So, all these characteristics make groupers mostly exposed to declines in reef habitat as a result of climate change and associated disturbances.

From the previous works it is become clear the grouper fish in the Gulf of Aqaba (Shipgl, 1985) or over all the world (Zapelini et al., 2017) become under threaten. However, information about their biological and ecological studies in the Gulf of Aqaba is scarce. Basic information on reproduction, food, and feeding as well as distribution and abundance and the territory of each species, are very important elements to know how preparing for management and conservation the population of grouper fishes in coral reef ecosystem.

The aim of this study was to explore spatial patterns of abundance, distribution for groupers along the Gulf of Aqaba at different depths. In addition to examining the degree to which the presence of Groupers are related 
to various physical and biotic habitat features of the coral reef ecosystem The survey will include all protectorates in South Sinai (Ras Mohamed, Nabq, Sharm El-Sheik City and Abu Galum), which were established in the gulf of Aqaba.

\section{MATERIALS AND METHODS}

The following section outlines the procedure for undertaking visual census surveys at the permanent monitoring sites after the Australian Institute of Marine Science (AIMS) fish monitoring protocol (Halford and Thompson 1994). The survey carried out in four sectors, namely Ras Mohammed National Park, Sharm El Sheikh City, Nabq Managed Resource Protected Area and Abu Galum Managed Resource Protected Area. Each sector includes four stations during October, November and December 2006 (Fig. 1) (Table 1). The sector location determined by using a GPS. Two divers cooperate to carry out the survey. One diver (observer) was equipped with a slate, identification sheet, pencil and data sheets. The observer conducts the 200 meter transect with width 10 meters. The transects were carried out at two depths 5 meters and $15 \mathrm{~m}$. The observer swims in a zigzag pattern (zigzag pattern used to ensure cover all the areas of transect) over the transect and counts the number of individuals of each grouper species sighted within the area of 5 meters on either sides. The location of the transects were selected at $5 \mathrm{~m}$ and $15 \mathrm{~m}$ depth for the reason that they could be cover depth ranging between 1 meters to 20 meters. The other diver follows the observer approximately five meters behind. Fish identification during this study follows Randall's guide in Red Sea Reef Fishes (1983). Also consider the characteristic behavioral groups into three (after Samoilys and Carlos, 2000) based on foraging pattern, crypticity and body size inferred from published literature and underwater observations. The behavioural groups are "cryptic serranids", "roving serranids", and "large mobile serranids". In an attempt to reduce variability in fish densities (due to diurnal influences on behavior) sampling excludes the high activity periods of early morning and late afternoon. Sampling has been limited between 0900 and 1600 . This time window also excludes periods of poor visibility caused by the low sun angle.

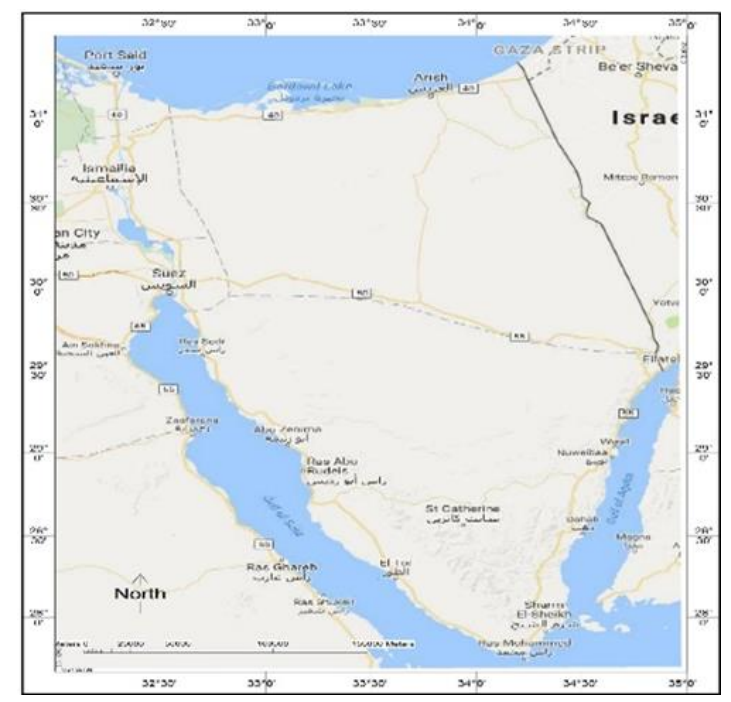

Figure (1): South Sinai Peninsula with Study area, 1 = Ras Mohammed National Park, $2=$ Sharm El Sheikh, $3=$ Nabq Managed Resource Protected Area and 4 = Abu Galum Managed Resource Protected Area.

Table (1): The latitude and longitude for all stations of thesurveyed sectors.

\begin{tabular}{cccc}
\hline \hline Sectors & Stations & North & East \\
\hline \multirow{2}{*}{ Ras Mohamed NP } & Marsa Ghozlany & $27.84436^{\circ}$ & $34.27585^{\circ}$ \\
& Old Quay & $27.73745^{\circ}$ & $34.23954^{\circ}$ \\
& South Berika & $27.77529^{\circ}$ & $34.21061^{\circ}$ \\
& Shark observatory & $27.73227^{\circ}$ & $34.25915^{\circ}$ \\
Sharm Al Sheikh & Ras um Sid & $27.847455^{\circ}$ & $34.313246^{\circ}$ \\
& Ras Nasrany & $27.964158^{\circ}$ & $34.418334^{\circ}$ \\
& Jakson Reef & $28.005461^{\circ}$ & $34.471445^{\circ}$ \\
& Gordon Reef & $27.984750^{\circ}$ & $34.452062^{\circ}$ \\
Nabq MPRA & Naklteltal & $28.145388^{\circ}$ & $34.444444^{\circ}$ \\
& Elmonkataa & $28.20616^{\circ}$ & $34.41908^{\circ}$ \\
& wadi ghorabi & $28.230795^{\circ}$ & $34.415859^{\circ}$ \\
Abu Galum MPRA & Kaber elbent & $28.392340^{\circ}$ & $34.447161^{\circ}$ \\
& Ras Mamleh & $28.730477^{\circ}$ & $34.627104^{\circ}$ \\
& Dehila south & $28.610714^{\circ}$ & $34.552363^{\circ}$ \\
& Dehila noth & $28.614322^{\circ}$ & $34.560475^{\circ}$ \\
\hline \hline
\end{tabular}




\section{RESULTS}

\section{Distribution of groupers (Serranids)}

Occurrence of the Groupers

The following species of Grouper were observed, which were found in the 16 stations, where 16 species related to five genera of groupers were recording as follows; Genus Cephalopholis: $C$. oligosticta, C.sexmaculata, C. argus, C. hemistiktos, and $C$. miniata; Genus Variola: V. louti; Genus Plectropomus: P. maculates and P. areolatus; Genus Anyperodon: A. Leucogrammicus; Genus Aethaloperca: A. rogaa; Genus Epinephelus: E. fasciatitus, E. polyphekadion, $E$. fuscoguttatus, E. malabaricu, E. tauvina, and $E$. areolatus. The most common species recorded at all sectors were $C$. miniata, $C$. hemistiktos, C. argus, $V$. louti, and E. fasciatus, which recorded in 12, 11, 10, 9, and 9 stations respectively. However only $C$. miniata and $C$. argus recorded in all station of the Ras Mohammed and Sharm El-Sheikh. C. oligosticta, A. Leucogrammicus, E. polyphekadion, E. fuscoguttatus, $E$. malabaricu and E. areolatus were represented only in one station.

Abundance of the grouper fishes

There was a very significant difference in the average abundance of groupers fish observed at each of the study sectors $(\mathrm{P}$ - value $=0.001)$. Average abundance was highest at Sharm El-Sheikh sector 54.125 $(\mathrm{SE} \pm 0.83) / 2000 \mathrm{~m}^{3}$ and lowest at Abu Galum 3.12 $(\mathrm{SE} \pm 0.61) / 2000 \mathrm{~m}^{3}$. Although no significant difference was found between Nabq and Abu Galum, (Fig. 2). However, the average abundance in Ras Mohamed and Nabq were recorded with $28.38(\mathrm{SE} \pm 0.39) / 2000 \mathrm{~m}^{3}$ and $3.13(\mathrm{SE} \pm 0.10) / 2000 \mathrm{~m}^{3}$.

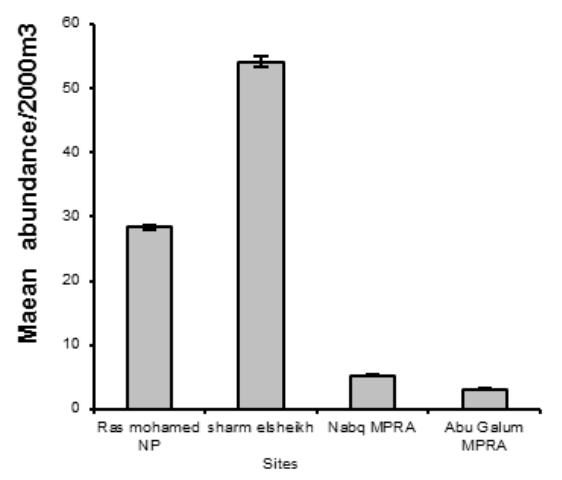

Figure (2): Mean abundance of groupers in all studied sectors.

The groupers abundance was studied in sixteen stations represented four sectors along the Gulf of Aqaba. One way analysis of variance showed a highly significant difference $(\mathrm{P}$-value $=0.0001)$ between all stations which indicated that the mean Groupers abundance varied from one station to another. Whereas the maximum mean abundance was recorded in the Ras Nasrany and Ras Um Sid with mean groupers abundance 76 $(\mathrm{SE} \pm 2.08) / 2000 \mathrm{~m}^{3}, 71(\mathrm{SE} \pm 2.0) / 2000 \mathrm{~m}^{3}$ respectively (Fig. 3). On the other hand the lowest mean abundance was found in Elmonkataa and Lagoona stations where mean grouper abundance were $2.0(\mathrm{SE} \pm 0.74) / 2000 \mathrm{~m}^{3}$ and $1.5(\mathrm{SE} \pm 0.94) / 2000 \mathrm{~m}^{3}$ respectively (Fig. 3).

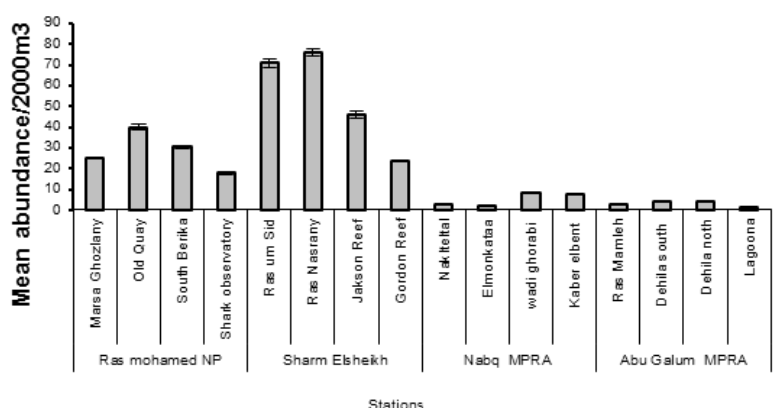

Figure 3: Mean abundance of groupers in all studied stations.

No significant difference was found for abundance of groupers (P-value $=0.59$ ) with depth, regardless of sit. With regard to mean abundance of different grouper species, regardless of the sites and depth (Fig. 4), there was a very significant difference $(\mathrm{P}$-value $=0$. 0001) between C. miniata, $C$. hemistiktos, and $V$. louti species. There was no significant difference in the mean groupers abundance between all other species. The C.miniata, C. hemistiktos, and $V$. louti had mean abundance $11.16(\mathrm{SE} \pm 2.9), 4.75(\mathrm{SE} \pm 1.16)$ and 2.1 $(\mathrm{SE} \pm 0.49)$ respectively. While the lowest mean abundance recorded for $E$. polyphekadion, $E$. fuscoguttatus, E. malabaricus and E. areolatus with same value 0.03 (SE \pm 0.1$)$ (Fig. 4).

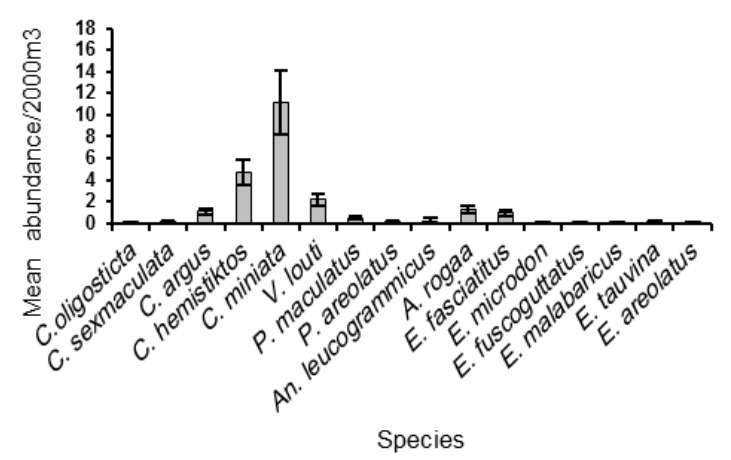

Figure (4): Mean abundance of different groupers species, regardless of sectors.

The mean abundance of grouper species was studied in two different depths $(15 \mathrm{~m}$ and $5 \mathrm{~m})$ for all stations. Tow way ANOVA showed that there is no significant different between mean abundance for all groupers species and depth $(\mathrm{P}-$ Value $=0.999)$, but there was a marginally higher in depth $15 \mathrm{~m}$ more than $5 \mathrm{~m}$ (Fig. 5). Whereas the heights mean abundance recorded for C.miniat were $11.3(\mathrm{SE} \pm 4.22)$ and $11(\mathrm{SE} \pm 4.3)$ at depth $15 \mathrm{~m}$ and $5 \mathrm{~m}$ respectively. However, there is a highly significant difference in mean value for all groupers species between sites $(\mathrm{P}$ value $=0.0001)$ and stations $(\mathrm{P}$ value $=0.0001)$. As seen in figures 6 , the mean value for all species very high in Ras Mohamed NP and Sharm Sheikh when compare to the other two sites Nabq MPRA and Abu Galum MPRA. 


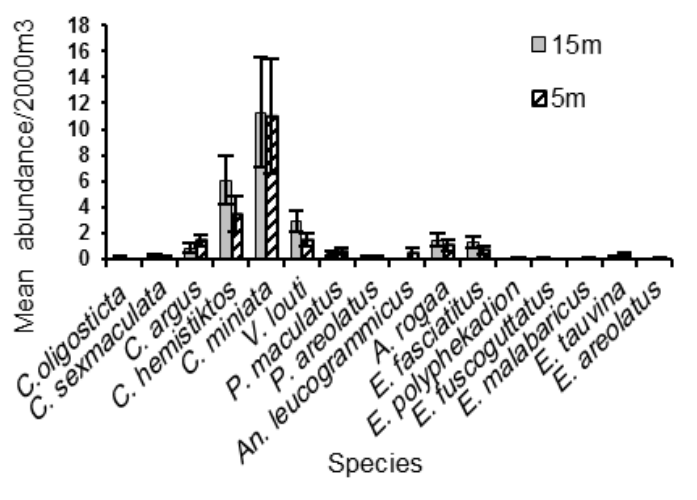

Figure (5): Mean Abundance of groupers species in different depth regardless to sectors.

The distribution of various species in all sectors showed that there were three sectors include most species, those sectors are Ras um Sid, Ras Nasrany and Jakson Reef. Also the presence of such species were with high abundance in the previously sites, especially the following six species, $C$. argu, $C$. hemistiktos, $C$. miniata, V. louti, A. rogaa and E. fasciatus.
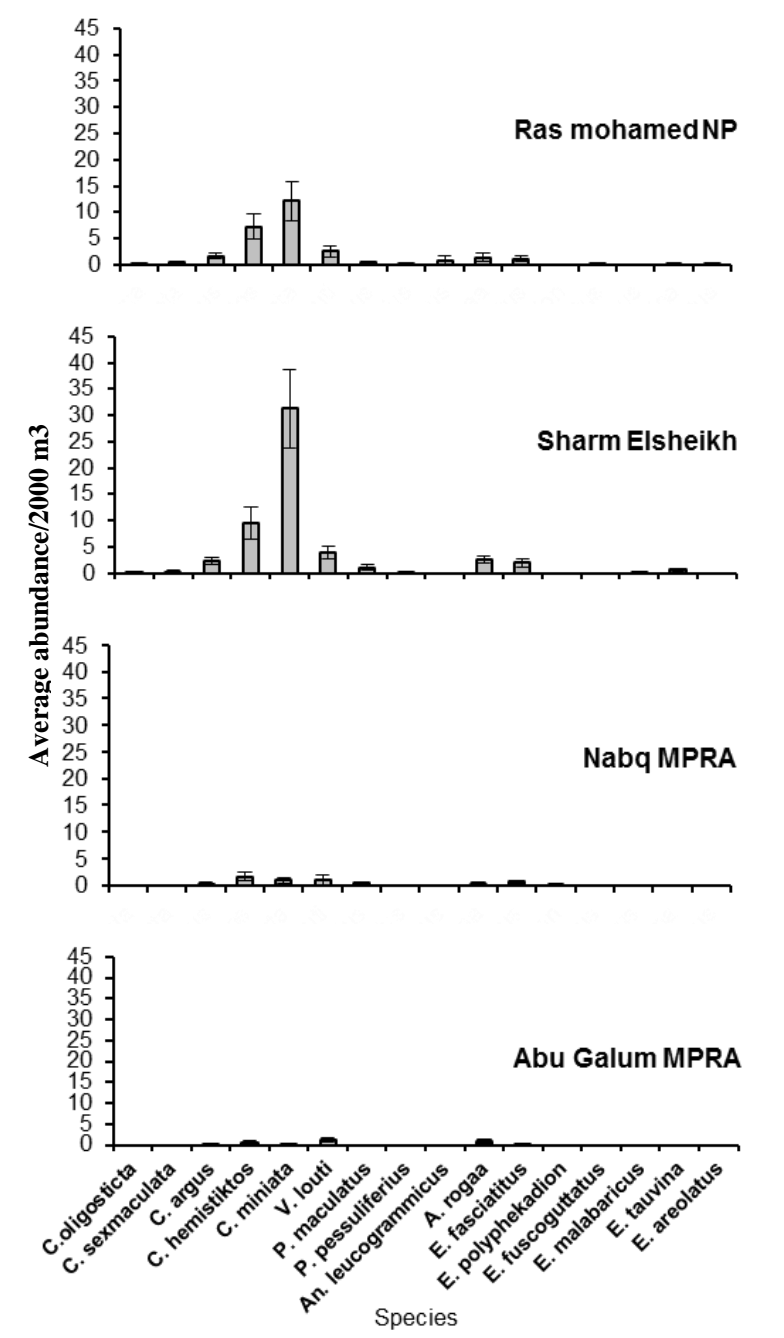

Figure (6): Comparison of mean Abundance of Groupers species in different sectors.
Abundance of the groupers fish according to ecological behavior.

During this study all groupers fish were reclassified according to the ecological behavior for each species (Samoilys and Carlos, 2000). One way analysis of variance (ANOVA) showed a highly significant difference $(\mathrm{P}$-value $=0.00431)$ between cryptic, roving and large mobile groupers, indicating that the density was different within each sectors for all variables. Figure (7) A indicating that density pattern for all groupers was largely driven by patterns in abundance of cryptic groupers, which were the most abundance behavioural group in most sites. The cryptic, roving and large grouper had mean abundance of 29.1 (SE \pm 0.371$), 2.5$ (SE \pm 0.194$)$, and 0.1 (SE \pm 0.017$)$, respectively.
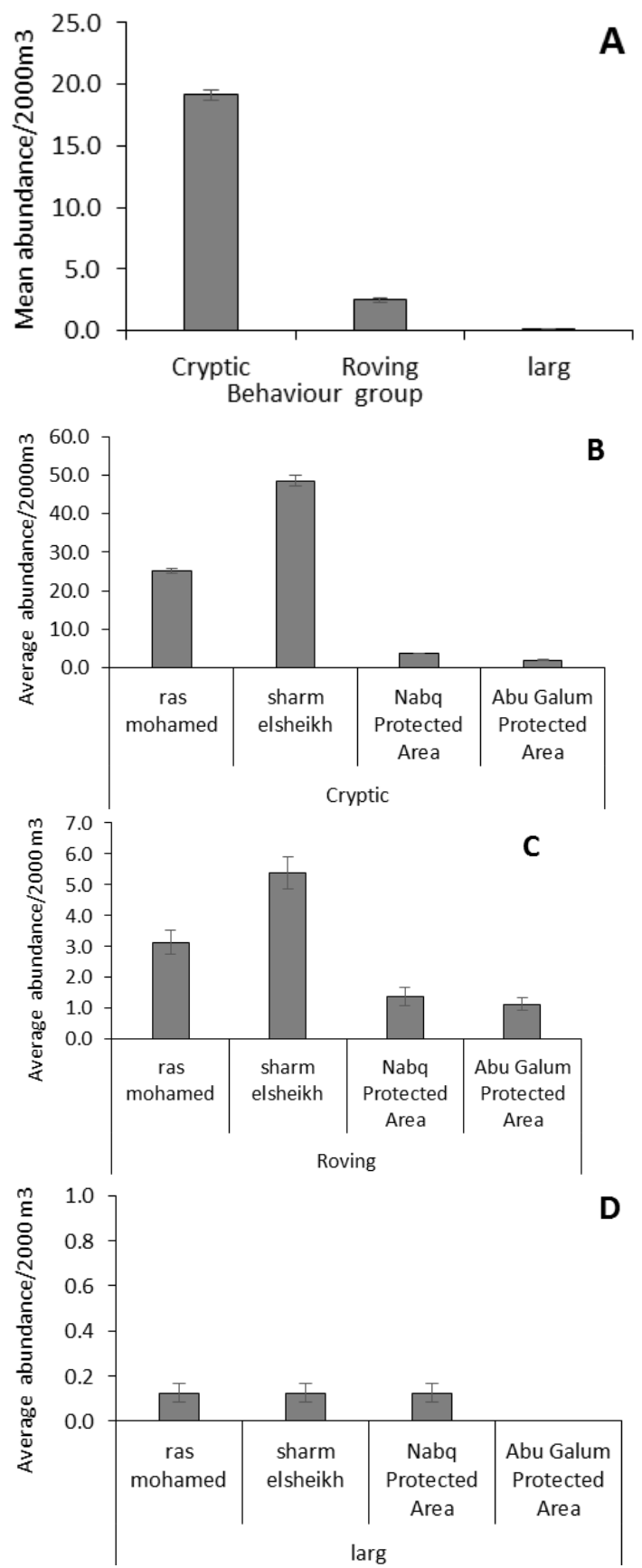

Figure (7): Mean abundance of ecological behivoural groups for all Grouper species at different Sectors 
Cryptic and Roving groupers were more abundance in two sites, namely; Sharm El Shiekh and Ras Mohamed NP than other sites in either Nabq MPRA and Abu Galum MPRA. Whereas the cryptic groupers mean abundance, were $45.6(\mathrm{SE} \pm 1.29)$ and 25.1 (SE \pm 0.61) at Sharm El Sheikh and Ras Mohamed NP respectively. However the roving grouper mean abundance, were 5.4 $(\mathrm{SE} \pm 0.52)$ and $3.1(\mathrm{SE} \pm 0.401)$ at same site respectively (Figure $7 \mathrm{~B}$ and $7 \mathrm{C}$ ). In case of large mobile groupers, there was no clear difference in all, sectors, where the mean abundance was recorded with the same value, being 0.125 (SE \pm 0.416), in Ras Mohamed NP, Sharm Elsikh and Nabq MRAP. While the large mobile groupers was not recorded at all in Abu Galum MRAP (Fig. 7 D).

The sixteen station surveyed showed significant variation in mean abundance for cryptic groupers ( $\mathrm{P}$ value $=0.001)$. The highest mean abundance were recorded generally at Ras um Sid, Ras Nasrany and Jakson Reef, being 69.5 (SE \pm 3.233$), 67(\mathrm{SE} \pm 3.1)$ and $41(\mathrm{SE} \pm 2.47)$ and the relative abundance for same sites were $19.12 \%, 18.43 \%$ and 11.28 respectively (Fig. 8). While the lowest mean abundance were recorded at Elmonkata, Dehila north and Naklteltal being 0.5 (SE \pm 0 . 5), 1 (SE \pm 0.06$)$ and 2.5 (SE \pm 0.14). The relatively abundance for the same sites were $0.14 \%$, 0.28 and $0.69 \%$ respectively (Fig. 8). However, there was no significant difference for roving $(\mathrm{P}$-value $=0.11)$ and large mobile groupers $(\mathrm{P}-\mathrm{value}=0.603)($ Fig. 8$)$.

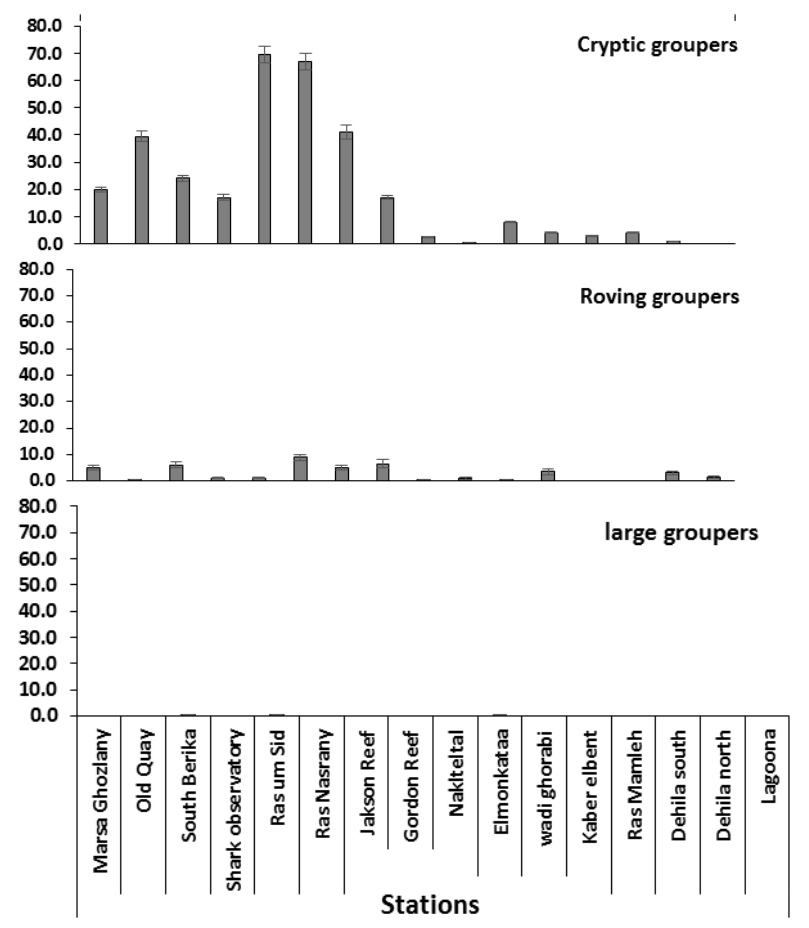

Figure (8): Mean Abundance of cryptic, roving and large Groupers in different stations.

The mean abundance of cryptic, roving and large mobile grouper as well determined at $15 \mathrm{~m}$ and $5 \mathrm{~m}$ depth in all study sectors. ANOVA analysis showed no significant variation in mean abundance of cryptic, roving and large groupers with depth, regardless of the sectors (Fig. 9). The highest mean abundance for cryptic groupers were estimated generally at depth 15 meters, being 21.3 (SE \pm 0.53 ) 4, where at depth $5 \mathrm{~m}$ it was 18.4 ( $\mathrm{SE} \pm 0.51)$. While roving grouper recorded with mean abundance at depth $15 \mathrm{~m}$ and $5 \mathrm{~m}$ with 3.4 (SE \pm 0.32) and 2.1 (SE \pm 0.21) respectively (Fig. 9). However, the mean abundance for large mobile grouper recorded at the same rate in 15 and $5 \mathrm{~m}$ depth, by $0.1(\mathrm{SE} \pm 0.2)$ (Fig. 9).

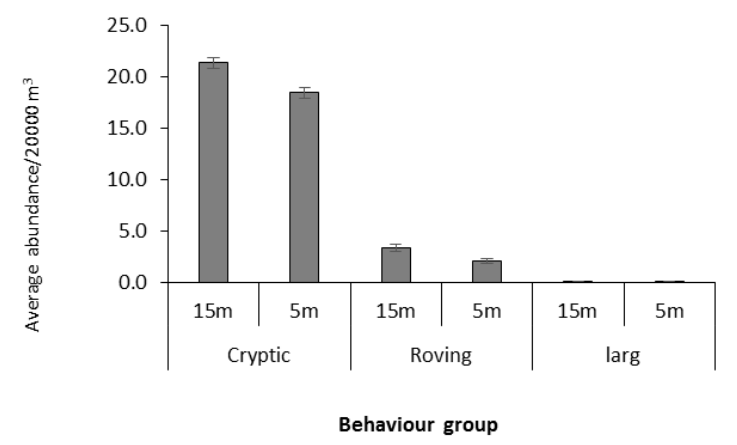

Figure (9): Mean Abundance of cryptic, roving and large groupers in different depths regardless to sectors.

\section{DISCUSSION}

This research was carried out to investigate the abundance of Groupers fish population (Family Serranidae) along the Gulf of Aqaba, inside four sectors within the marine protected areas of South Sinai (Ras Mohamed National Park, Sharm El-Sheikh City, Nabq Managed Resource Protected Area and Abu Galum Managed Resource Protected Area). Those protected areas along the Sinai coast, declared by the Egyptian Government, to effectively protect the entirety of Egypt's Gulf of Aqaba littoral zone (Pearson and Shehata, 1998).

All of the reefs selected for the survey were similar in being continuous fringing reefs, with two exceptions; Jackson Reef and Gordon reef (in Sharm El Sheikh Sector), which are offshore reefs, in order to reduce habitat influences. Different substrates vary locally, which in turn may have influenced the fish communities to some extent. However, substrate composition did not vary over the regions or affect the fish communities largely. This suggests that factors such as fishing pressure and urban development are likely to be more responsible for observed differences in fish populations (Ashworth and Ormond, 2005).

\section{Occurrence of the groupers}

Randall (1983) recorded 19 grouper species belonging to the Subfamily Epinephelinae all over Red Sea. In the present study, 16 grouper species out of the 19 confirmed by Randall (1983) were recorded in the Gulf of Aqaba. This result is in agreement with El-Dawi (2000), who investigated reef fishes in the Protectorates of Southern Sinai: Ras Muhammed NP, Nabq MRPA and Abou Galum MRPA were surveyed between September 1994 and July 1995. All species recorded by El-Dawi (2000) are the same in this study except for $E$. chlorostigma and E. microdon which were mentioned 
only in El-Dawi study, while E. polyphekadion and $P$. areolatus were recorded only in this research. These differences may have been due to the difficulty of correctly identifying species. This difficulty is attributable to past taxonomic confusion, the similarity of colour pattern of some species, ontogenetic changes and other variations in colour patterns (Heemstra and Randall, 1993).The results obtained in the present study are mostly well matched with Ghorab et al. (1983) and El-Dawi (2000) whose studied the abundance of grouper in the same study area. Whereas, the highest numbers of grouper species were recorded in Ras Mohamed NP and Sharm Elsheik sectors with 12 species for each, followed by Nabq MRPA and Abu Galum MRPA sectors with 8 and 6 species respectively. It was similarly evident that, the species number in Nabq is higher than in the previous studies, this can reasonably be explained by applying fisheries management in Nabq where fishing is prohibited in about $60 \%$ of the coastal line (Pearson and Shehata, 1998).

\section{Abundance of the groupers fish.}

Comparison of the groupers fish abundance in the four study sectors revealed an interesting trends, particularly when each sector was marked fished or unfished, as classified by Pearson and Shehata (1998) and Ashworth (2004), the abundance of groupers was found to be significantly greater within unfished area. Increases in density of targeted fishes in unfished area have frequently been seen, especially with major commercial species such as groupers (Galal et al., 2002; Ashworth and Ormond, 2005; UNEP and WIOMSA. 2015).

Ashworth (2004) studied the coral reef fish's abundance in south Sinai protectorates, and confirmed that, the fish abundance in unfished area is higher than that of the fished areas. A similar pattern was seen by Roberts and Polumin (1992) who additionally recorded significantly higher densities of some coral fishes in unfished areas than in lightly and heavily fished areas, which corresponds with result from this study. The mean abundances of all grouper species in Ras Mohamed NP and Sharm El Sheikh Sector are higher than in Nabq MRPA and Abu Galum MRPA sector. That may be due to the effect of fishing in Nabq and Abu Galum sectors and since the coral cover and structure of the habitat are approximately the same in all four sectors (internal report/South Sinai Protectorates $2005,2006)$. The obtained results in present study agree with Ashworth, (2004) and El-Dawi (2002). As well, the obtained result mostly supported by Limmon et al. (2017) who pointed out, the importance of the management of the grouper fish by various ways, ranging from the declaration of marine protected areas, to the establishment of a non-taking zone and has been shown to be an effective management strategy to increase the population and help maintain and increase the grouper stock and diversity.

In recent decades, development pressure has been extremely high around the town of Sharm El Sheikh, with development (mostly hotels) now stretching along the coast from the northern edge of Ras Mohammed NP to the southern edge of Nabq MRPA (Hawkins and Roberts, 1994; Pearson and Shehata, 1998). The development has been well managed and regulated by South Sinai Protectorates to avoid impacts, such as infilling and sewage discharge into the sea, prohibited (Hawkins and Roberts 1994; Pearson and Shehata 1998). SCUBA diving and snorkeling are a major industry in Ras Mohammed NP and around the towns of Sharm El Sheikh. These activities are known to cause damage to coral reefs (Medio et al., 1997; Hawkins et al., 1999). Nevertheless, tourism and its associated effects do not appear to have had large effects on fish populations around Ras Mohammed NP and Sharm El Sheikh Sectors, with few instances of significantly lowered density in these areas compared to Nabq MRPA sector which has much lower levels of tourism impacts. The findings of the present study are in agreement with studies mentioned above, where the relative abundance of groupers fish in Sharm El-Sheikh stations is represented by $59.6 \%$ from total groupers in all sectors. In addition, almost all of the hotels in Sharm El Sheikh control the fishing activity along the coast by allowing no recreational or commercial fishing boats in front of the hotels (personal observations).

Jones (1991) and Sluka et al. (2001) confirmed there was correlated fish abundance or biomass and structural features of reefs or between offshore and onshore reef. Each of these studies has shown that some features of a particular site, usually associated with structural complexity, influenced significantly the distribution or abundance of coral reef fishes (Sluka et al., 2001). However, in the present study the results obtained are not well-matched with Jones (1991) and Sluka et al., (2001), where the highest abundance of groupers fishes were recorded in inshore reef like Ras Nasrani (76 $\mathrm{SE} \pm 2.08)$ and Ras Um Sid (71 SE \pm 2.0$)$ while offshore reefs like Jackson Reef (46 $\mathrm{SE} \pm 1.5$ ) and Gordon reef (23 $\mathrm{SE} \pm 0.5$ ) are lower in terms of Grouper fish abundance. In spite of the designation of some sites as unfished, some illegal fishing takes place in such sites (personal observations). That is because those sites do not undergo full control by the Ras Mohamed NP; however, as the recreational diving being practiced at both sites during most of the day, the fishing activities are limited.

Densities of each grouper species were also examined. Where all of the 16 species recorded in this study showed increased density in both Ras Mohamed NP and Sharme El Sheikh Sectors (unfished areas). The three most numerous groupers were $C$. miniata, $C$. hemistiktos and $V$. Louti. Three of them represented about $79.5 \%$ of the total recorded fishes in the present study, as confirmed by the previous study near Sharm El Sheikh, Ras Mohammed NP and Nabq MRPA (Ashwarth, 2004). C. miniata represented the highest percentage $49 \%$ of the total counted fishes. The reason behind that might be explained by the occurrence of this species in social groups, where each group is composed of 4 to 6 individuals. 


\section{Abundance of the groupers fish according to ecological behaviour}

There are a few studies that addressed the grouper abundance from the point of ecological view, one of them Pears (2005) described and compared characteristics of groupers abundance on the GBR and the Seychelles Islands, and provided abundance estimates for three behavioural groups (cryptic grouper, roving grouper, and large mobile grouper). He also found that the abundance of the cryptic and roving behavioural groups is higher than that of the large mobile grouper species in both regions.

The results obtained in the present study, regarding the abundance of the different ecological group of groupers, completely agree with Pears (2005). Similarly, the abundance of the cryptic and roving groupers is higher than large mobile groupers, which are ranked rare in all the studied sectors. While cryptic and roving grouper included both abundance and rare species, the large mobile groupers species were all rare. Current research are well-matched with Pears (2005), where the cryptic groupers are considered the most dominant in all of the studied sectors, where it represented $87.5 \%$ followed by roving groupers estimated at $12 \%$ of the total species, and large mobile occurred in very low percentage $(0.4 \%)$ thus considered rare species. Most species of cryptic grouper in particular are small-bodied and are not a highly targeted fishing species compared to the roving and large mobile grouper. The pattern of occurrence for each of the three different groups was similar in all sectors, except for Abu Galum MRPA sector where no large mobile grouper was recorded, this is mostly attributed to the effect of overfishing. These results are considered serious and need furthermore scientific research to be conducted and better management measures, which decline in the abundance of large grouper species may affect the ecological role of species in the ecosystem as a major predator, as well as an impact on the community structure (Britten et al., 2014; Mat Piah et al., 2018).

There are several possible reasons for this pattern. First, it is possible that roving and large grouper are more susceptible to fishing pressure by line and spear fishing than cryptic grouper (Ashworth, 2004; Zapelini et al., 2017). Second, because of large territory and long-distance spawning migration of roving and large grouper (Bolden, 2000). Therefore, the species that migrate to spawn will certainly spend some period outside of the reserve boundaries. The longer the time spent outside the reserve, the more vulnerable fish become to fishing mortality (Chapman and Kramer, 1999). The second argument is more acceptable. Many aggregation sites for spawning of Pelctopomus maculatus, Epinephelus Fuscoguttatus and Epinephelus Malabricous are known to local fisherman and recreational fishing outside the boundaries of protectorates. This finding is in full agreement with Tupper (2002) who found large grouper (Nassau grouper) spawning aggregation roughly $40 \mathrm{~km}$ from the reserve area. In contrast, cryptic groupers are known to aggregate just 200 - $340 \mathrm{~m}$ outside the eastern boundary of the park, at the southeastern tip of South Caicos.
Thus, because of the roving and large grouper spend longer periods outside the reserve boundaries; they will receive lesser benefit from the reserve than cryptic species. The third reason is related to an effectively damaging fishing technique, such as hand-lining from the reef edge or from a boat (Galal et al., 2002) and trawling by line and artificial bites (personal observations), both of which are highly selective for high predators especially grouper fishes. In addition to increasing demand for fish by the restaurants of the tourist resorts of South Sinai until recently a seasonal fishery was allowed in Ras Mohammed NP sector for the lethrinid Lethrinus nebulosus (local name 'Shour') but is now prohibited to safeguard stocks (Salem, 1999), nevertheless, frequent incidences of illegal fishing within reserve boundaries have been reported (personal observation).

\section{REFEANCES}

ALMANY, G.R. 2004. Does Increased Habitat Complexity Reduce Predation and Competition in Coral Reef Fish Assemblages? Oikos 106: 275-285.

ASHWORTH, J. S. 2004. The effects of Protected Area Status on Fish and Mollusc Stocks in South Sinai, Egypt. University Marine Biological Station Millport, U. of London. Doctor of Philosophy (PhD), Marine Biology.

ASHWORTH, J.S., AND R.F.G. ORMOND. 2005. Effects of fishing pressure and trophic group on abundance and spillover across boundaries of a notake zone. Biological Conservation 121:333-344.

AUSTER, P.J. 2005. Predatory Behavior of Piscivorous Reef Fishes Varies with Changes in Landscape Attributes and Social Context: Integrating Natural History Observations in A Conceptual Model. In: Diving for Science 2005, Proceedings of the American Academy of Underwater Sciences, Connecticut Sea Grant, Groton, pp 115-127.

AYLING, T., D. RYAN, AND M.A. SAMOILYS. 2000. Trends in Common Coral Trout Populations on The Great Barrier Reef: A Report to The Queensland Fish Management Authority. Queensland Fisheries Service Dept. of Primary Industries, Brisbane.

BIRKELAND, C. 1997. Disposable Income in Asia - A New and Powerful External Pressure Against Sustainability of Coral Reef Resources on Pacific Islands. Reef Encounter 22: 9-13.

BOLDEN, S.K. 2000. Long-Distance Movement of A Nassau Grouper (Epinephelus striatus) to A Spawning Aggregation in The Central Bahamas. Fisheries Bulletin 98(3): 642-645.

BRITTEN, G.L., M. DOWD, C. MINTO, F. FERRETTI, F. BOERO, AND H.K. LOTZE. 2014. Predator Decline Leads to decreased Stability in a Coastal Fish Community. Ecology Letters 17: 15181525.

CHAPMAN, M.R., AND D.L. KRAMER. 1999. Gradients in Coral Reef Fish Density and Size 
Across the Barbados Marine Reserve boundary: Effects of Reserve Protection and Habitat Characteristics. Marine Ecology Progress Series 181: 81-96.

DALZELL, P. 1996. Catch Rates, Selectivity and Yields of Reef Fishing. In: Polunin NVC and Roberts CM (eds) Reef Fisheries, pp 161-192. Chapman \& Hall, London.

EL DAWI, E.F.A. 2000. Diversity, Habitats and Seasonal Distribution of Fish in Three Protectorates of Southern Sinai on the Red Sea, Egypt. Qatar University Science Journal, 20: 111-124

GALAL, N. 1999. Studies on The Coastal Ecology and Management of the Nabq Protected Area, South Sinai, Egypt. Ph.D. thesis, University of York, York, UK.

GALAL, N., R.F.G. ORMOND, AND O. HASSAN. 2002. Effect of A Network of No-Take Reserves in Increasing Catch Per Unit Effort and Stocks of Exploited Reef Fish at Nabq, South Sinai, Egypt. Marine and Freshwater Research 53: 199-205.

GHORAB, H.M., A.R. BAYOUMI, AND A.A. HASSAN. 1983. Studies on Fish of the Family Serranidae from the Northwestern Region of the Red Sea. Bulletin of the Institute of Oceanography and Fisheries Cairo, 9: 256-265.

GIGLIO, V.J., M.G. BENDER, C. ZAPELINI, AND C.E.L. FERREIRA. 2017. The End of the Line? Rapid Depletion of a Large-Sized Grouper through Spearfishing in the Southwestern Atlantic. Perspectives in Ecology and Conservation, 15(2): $115-118$

GRANDCOURT, E. 2005. Demographic Characteristics of Selected Epinepheline Groupers (family: Serranidae; subfamily: Epinephelinae) from Aldabra Atoll, Seychelles. Atoll Research Bulletin 593: 200216.

HALFORD, A.R. AND A.A. THOMPSON. 1994 Visual Census Surveys of Reef Fish. Long Term Monitoring of the Great Barrier Reef.Standard Operational Procedure Number 3. Australian Institute of Marine Science, Townsville

HAWKINS, J.P., C.M. ROBERTS, T. VAN'T HOF, K. DE MEYER, J. TRATALOS, AND C. ALDAM. 1999. Effects of Recreational Scuba Diving on Caribbean Coral and Fish Communities. Conservation Biology 13: 888-897.

HAWKINS, J.P., AND C.M. ROBERTS. 1994. The Growth of Coastal Tourism in the Red Sea: Present and Future Effects on Coral Reefs. Ambio 23: 503508.

HEEMSTRA, P.C., AND J.E. RANDALL. 1993. FAO Species Catalogue. Groupers of the World (Family Serranidae, Subfamily Epinephelinae). An annotated and Illustrated Catalogue of the Grouper, Rockcod, Hind, Coral Grouper and Lyretail Species known to Date. FAO Fisheries Synopsis, 125, Vol. 16. Rome FAO, $382 \mathrm{p}$.

JEFRI, E., N.P. ZAMANI, B. SUBHAN, AND H.H. MADDUPA. 2015. Molecular Phylogeny Inferred from Mitochondrial DNA of the Grouper
Epinephelus spp. in Indonesia Collected from Local Fish Market. Biodiversitas, 16(2): 254-263.

JONES, G.P. 1991. Postrecruitment Processes in the Ecology of Coral Reef Fish Populations: A Multifactorial Perspective. In The Ecology of Fishes on Coral Reefs (Sale, P. F., ed.), pp. 294-328. New York: Academic Press.

LIMMON. G.V., R. FREDERIK, A.S. KHOUW, M. GRATIA, AND P. JESAYA. 2017. The Diversity of Grouper ( Epinephelinae ) in Ambon Island , Maluku , Indonesia. Kagoshima University Research Center for the Pacific Islands 58 (1): 23-29.

LINDBERG, W.J., T.K. FRAZER, K.M. PORTIER, F. VOSE, J. LOFTIN, D.J. MURIE, D.M. MASON, B. NAGY, AND M.K. HART. 2006. DensityDependent Habitat Selection and Performance by a Large Mobile Reef Fish. Ecological Applications16: 731-746.

MAPSTONE, B.D., C.R. DAVIES, L.R. LITTLE, A.E. PUNT, A.E.D. SMITH, F. PANTUS, D.C. LOU, A.J. WILLIAMS, A. JONES, A.M. AYLING, G.R. RUSS, AND A.D. MCDONALD. 2004. The effects of Line Fishing on the Great Barrier Reef and Evaluations of Alternative Potential Management Strategies. 52, Cooperative Research Centre for the Ecologically Sustainable Development of the Great Barrier Reef, Townsville.

MAT PIAH, R., N.H. ABDUL KADIR, A. KAMARUDDIN, M.N. AZAMAN AND M.A. AMBAK. 2018. Analysis of Historical Landing Data to Understand the Status of Grouper Populations in Malaysia. Malaysia Applied Biology 47(3): 49-58

MEDIO, D., R.F.G. ORMOND, AND M. PEARSON. 1997. Effects of Briefings on Rates of Damage to Corals by Scuba Divers. Biological Conservation 79: 91-95.

ORMOND, R.F.G. 1980. Aggressive Mimicry and other Interspecific Feeding Associations among Red Sea Coral Reef Predators. Journal of Zoology, London, 191: 247-262.

PARRISH, J.D. 1987. The Trophic Biology of Snappers and Groupers. In: Polovina JJ and Ralston S (eds) Tropical Snappers and Groupers: Biology and Fisheries Management, pp 405-465. Westview Press, Boulder, Colorado.

PEARS, R.J. 2005. Comparative Demography and Assemblage Structure of Serranid Fishes: Implications for Conservation and Fisheries Management. Ph.D thesis, James Cook Uni-versity, Townsvill.

PEARSON, M.P., AND A.E. SHEHATA. 1998. Protectorates Management for Conservation and Development in the Arab Republic of Egypt. Parks 8: 29-35.

POGONOSKI, J.J., D.A. POLLARD, AND J.R. PAXTON. 2002. Conservation overview and action plan for Australian threatened and potentially threatened marine and estuarine Environment Australiafishes, Environment Australia. Canberra. 373 p.

PROKOP, F. 2002. Australian Fish Guide. Australian Fishing Network, Victoria, Australia. 2nd reprint. Pp 224 
RANDALL, J.E. 1983. Red Sea Reef Fishes. Immel Publishing Limited, London.

ROBERTS, C.M., AND N.V.C. POLUNIN. 1992. Effects of the Marine Reserve Protection on Northern Red Sea Fish Populations. Proceedings of the Seventh International Coral Reef Symposium, Guam 2: 969-977.

ROBERTS, C.M., S.G. EL-ETREBY, A.A. GHOBASHY, AND M.A. ZYADAH. 1993. Coral Reef Groupers (Family: Serranidae) in South Sinai IV. Tagging Experiemnt and Population Recovery of Cephalopholis Hemistiktos (Ruppell, 1830) in Na'ama Bay, Sharm Elsheikh. Journal of the Egyptian German Society of Zoology 12: 21-31

SADOVY, Y.J., M.T.CRAIG, A.A. BERTONCINI, K.E. CARPENTER, W.W.L. CHEUNG, J.H. CHOAT, A.S. CORNISH, S.T. FENNESSY, B.P. FERREIRA, P.C. HEEMSTRA, M. LIU, R.F. MYERS, D.A. POLLARD, K.L. RHODES, L.A. ROCHA, B.C. RUSSELL, M.A. SAMOILYS, AND J. SANCIANGCO. 2012. Fishing Groupers Towards Extinction: a Global Assessment of Threats and Extinction Risks in A Billion Dollar Fishery. Fish and Fisheries, 14: 119-136.

SALEM. M. 1999. Management of fishing in the Ras Mohammed National Park with Special Reference to the Fishery of Lethrnius nebulosus (Forsskal, 1775). $\mathrm{PhD}$ thesis. York University.Uk

SAMOILYS, M.A., AND G. CARLOS. 2000. Determining Methods of Underwater Visual Census for Estimating the Abundance of Coral Reef Fishes. Environmental Biology of Fishes 57: 289-304.

SAMOILYS, M.A. 1997. Movement in A Large Predatory Fish: Coral Trout, Plectropomus leopardus (Pisces: Serranidae), on Heron Reef, Australia. Coral Reefs 16: 151-158.

SHPIGEL, M. 1985. Aspects of the biology and ecology of the Red Sea groupers of the genus Cephalopholis (Serranidae, Teleostei). Ph.D Dissertation, Tel Aviv University (in Hebrew, summary in English).

SLUKA, R.D., M. CHIAPPONE, AND K.M. SULLIVAN. 2001. Influence of Habitat on Grouper Abundance in the Florida Keys, U.S.A. Journal of
Fish Biology, 58: 682-700.

SLUKA, R.D., M. CHIAPPONE, K. SULLIVAN, K. AND R. WRIGHT. 1996. Habitat and Life in the Exuma Cays, the Bahamas the Status of Groupers and Coral Reefs in the Northern Cays. The Nature Conservancy.

SOUTH SINAI PROTECTORATES. 2005. Rapid Ecological Assessment for Abu Galum Managed Resource Protected Area. Egyptian Environmental Affairs Agency. pp: 46

SOUTH SINAI PROTECTORATES. 2006. Ecological Surveys and Impact Assessment of The Mangroves (Avicennia marina) in Nabq Managed Resource Protected Area. Egyptian Environmental Affairs Agency. pp: 77.

SULLIVAN, K.M., AND R.D. SLUKA. 1996. The Ecology of Shallow-Water Groupers (Pisces: Serranidae) in the Upper Florida Keys, USA. Pages 76-86 in F. Arrequin-Sanchez, J.L. Munro, M.C. Balgos and D. Pauly (eds.). Biology, Fisheries and Culture of Tropical Groupers and Snappers. The International Center for Living Aquatic Resources Management Conference proceedings. 48-449 pp.

TUPPER, M. 2002. Essential Fish Habitat and Marine Reserves for Groupers in the Turks and Caicos Islands. Proceedings of the Gulf and Caribbean Fisheries Institute, Vol. 53: 606-622.

UNEP AND WIOMSA. 2015. The regional State of the Coast Report: Western Indian Ocean. United Nations Environmental Programme (UNEP). The Western Indian Ocean Marine Science Association (WIOMSA), Nairobi, Kenya, pp: 546.

WOLF, J. 1999. Groupers and their kin. Odyssea. Journal Marine Aquarium Society Los Angeles 44

ZAPELINI, C., J.G. VINICIUS, C.C. RENATA, G.B. MARIANA, AND C.G. LEOPOLDO. 2017. Assessing Fishing Experts' Knowledge to Improve Conservation Strategies for an Endangered Grouper in the Southwestern Atlantic. Journal of Ethnobiology, 37(3): 478-493

ZYADAH, M.A. 1991. Community Studies on Coral Reef Fishes: Family Serranidae of S. Sinai, Egypt. M. Sc. Thesis on Zoology. Faculty of sciences, Suze canal university. 


\section{دراسة توزيع كثافة أسماك الجروبر في منطقه خليج العقبة}

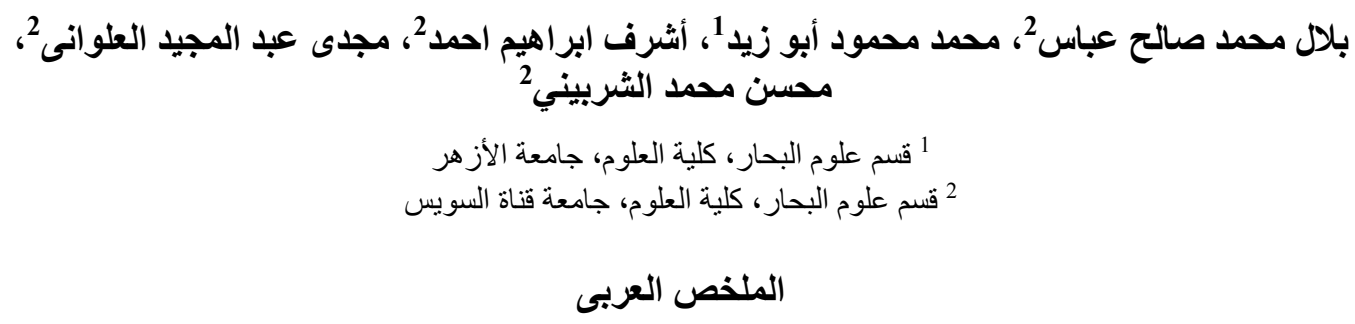

تمت دراسة كثافه نوزيع أسماك الجروبر(عائلة السرنيدى) في سته عشر موقعاً تمثل أربع مناطق بامتداد خليج العقبة. حيث كان العدد الكلي للأنواع المسجلة من كافة المو اقع هو ستة عشر نوعاً من أسماك الجروبر التي تنتمى لخمسة اجناس. سُجلت أعلى كثافة لجميع أنواع أسماك الجروبر في كل من محمية رأس محمد و مدينه شرم الثيخ وتلتهما في الكثافة محميتي نبق و أبو جالوم على هنى التوالي. أما على مستوى المواقع فقد نصدر الترنيب العام لكثافة أسماك الجروبر كل من موقعي رأس نصراني

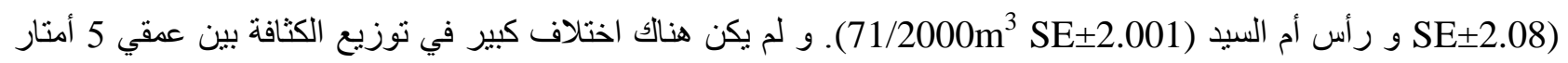
و15مثراً في جميع المو اقع التي شملتها الدراسة. تم تقسيم أسماك الجروبر وفقاً للسلوك الإيكولوجي لكل نوع، و تحديد كثافتها

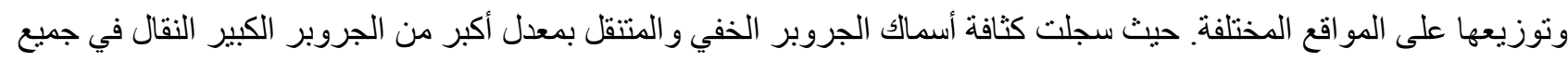
المواقع التي شملتها الدراسة. اتسمت أنماط نوزيع كثافة أسماك الجروبر المقسمة وفقا للسلوك الأيكولوجي، في جميع المناطق بالتشابه باستثناء محمية أبو جالوم حيث لم يسجل بها أي من الجروبر الكبير النقال. و هو ما نعزوه لما تتعرض له المحمية من

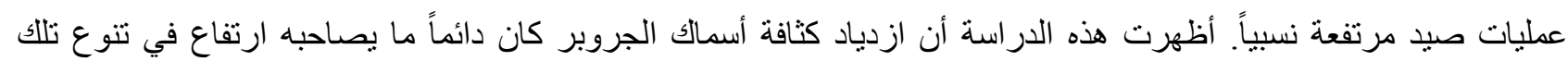
الأسماك بشكل عام في جميع المو اقع. 